\title{
The Positive and Negative News Coverage Released by the Media that Influenced Athletes' Psychology
}

\author{
$1^{\text {st }}$ Heny Setyawati \\ Facuty of Sports Sciences \\ Universitas Negeri Semarang \\ Semarang, Indonesia \\ henysetyawati@mail.unnes.ac.id
}

\author{
$2^{\text {nd }}$ Tandiyo Rahayu \\ Facuty of Sports Sciences \\ Universitas Negeri Semarang \\ Semarang, Indonesia \\ tandiyorahayu@mail.unnes.ac.id
}

\begin{abstract}
The development and the performance of athletes need to be disclosed to the society in general, through mass media though uncontrolled news may give negative side effect which is contra productive for the sports coaching, including mental defectiveness of an athlete. This study is to examine The positive and negative news coverage released by media that psychologically influenced athletes'. The participants were athletes who are from Central java, a total of 10 athletes, who are informed in mass media. They are in potential ages with national level achievement. They are experienced in their own expertise of sport within more of 7 years. They are in progress doing training in the training center basecamp and live in dormitory. The data were collected from interview. The analysis of data by qualitative. Mass media has an important role for an athlete as a constructive criticism shall be accepted as reality. Criticism on the media are helpful in improving her weakness. Athletes actually feel delighted when media covers them. The news in media can boost athletes motivation and popularity. Positive news covered in mass media makes them feel proud. News covering the weaknesses of athletes can bring about self-reflection and self-improvement.
\end{abstract}

Keywords-sports news, the positive news coverage, the negative news coverage, mental toughness.

\section{INTRODUCTION}

In development and improvement of sports achievement, one of the main domains that could not be underestimated is psychological aspect. Here, sports achievement, besides determined by physical, technical and tactical aspects, is also influenced by psychological aspect. Therefore, psychological preparation is urgently required to ensure the optimal physical performance [1]. The role of psychological aspect in an achievement is regarded as important for those who are involved in elite sports.

In a competition, a success is at least determined by 90$95 \%$ mental [2]. This fact, an immense factor on mental aspect is unavoidable. In a competition event among elite athletes, the winner is the one who has robust mental toughness.

The performance in sports is influenced by not only positive but also negative expectation towards a particular matter. A positive expectation will definitely give positive impact towards the performance, and vice versa on negative expectation [3]. Further, the degree of positive and negative expectations of a person is influenced by self-belief that she/he will finish the required task well [4].

In some particular situations, though athletes has practiced well and showed significant improvement from their practice, the reality in a real competition might be different as they could not perform the best. Further, the effectiveness of their favorable movement during the practice seems to disappear in a competition. Besides that, the speed of their movement is drastically decreased whereas they become unbelievably rigid. That athlete might have problems in psychological aspect. Therefore they tend to be slightly doubtful in making a decision, face difficulty in determining the right momentum to address an attack, lose concentration when defending and do not have any courage to change their strategy due to anxiousness.

\section{MATERIALS AND MEHODS}

In a competition event, psychological, physical aspects as well as skills contribute to best achievement. When the ability of an athlete is similar to the ability of the enemy, the aspect that determines the winning is mental thoughnees. Therefore, an athlete who has good mental toughness will be likely more successful in winning a competition.

Many failures of an athlete in a competition are presumably caused mainly by mental aspect. Hence, physical ability and skill trained to an athlete for years would be in vain if they do not have a robust mental toughness.

Psychological condition of athletes in the form of strong mental toughness during a competition becomes one of the essential elements in determining their success. Competitions under high psychological pressure will obviously disrupt the concentration of athletes.

The formation of strong mental toughness on athletes is basically influenced by two factors, internal and external factors. An internal factor relates to the internal condition of athletes including personality structure whereas an external factor is the environmental condition of athletes, including family, rehearsal or society environment. 
Meanwhile external factor that influences athletes is an environmental condition surrounding them, including facility, rehearsal or society circumstances. One of the parts of society circumstances is the press or broadcast through mass media related to athletes' achievement or personal problems not to mention sports activity.

Sports news with its variety is viewed as if "a piece of a coin" by the sports coaches and athletes. Therefore, the development and the performance of athletes need to be disclosed to the society in general, through mass media though sometimes uncontrolled news may give negative side effect which is contra productive for the sports coaching, including mental defectiveness of an athlete. This study is to examine the Positive and Negative News Coverage Released by the Media that Influenced Athletes' Psychology.

The research design used qualitative approach [5]. The research subjects were 10 athletes from Central Java, who are informed in mass media. They are in potential ages with national level achievement. They are experienced in their own expertise of sport within more of 7 years. The athletes are from roller skates, judo, tae kwondo, boxing, wushu and volley ball.

The data were collected from interview, each athlete was interviewed 3 times for 30 minutes. The guideline of interview is based on the need of the data in accordance with main objectives to investigate how the athletes' responses toward the news in mass media are. The interview was conducted personally, which was to be likely elicited comprehensive and prolonged information. The interview process was conducted freely and semi-structured alleviate boredom.

The analysis of data uses qualitative data analysis which was administered interactively and continuously until it was finished [6]. The procedure of data analysis were: data reduction, data display, and conclusion drawing verification. The data are verified through expert cross checking, they are: the coach, sport committee, journalist, communication expert, psychology expert.

\section{RESULTS AND DISCUSSION}

Amir Mahmud the chief editor of Suara Merdeka newspaper and sports commentator, says that normatively according to Act No 40 year 1999 about mass media stating that the reality from that construction implies actually on how media can participate, media content can give as if writing down on a piece of blank space. Media can fill in anything oriented on related matters there. The problem is on how media discuss issues which are more ethical, showing badness-goodness, caring or not caring, feeling of responsibility disclosing the reality and interdependence. The independence shall not be interpreted as a matter based on a volume of balance, but on how media express accentuation of an issue towards motivation for greater good.

In the framework of journalism, a sport is an exploration object. On how and what should be reported by the media are mostly featuring the commercial aspects. There is occasionally a more noble purpose that shall be highlighted which is, supervision aspect. Nevertheless an integral part in that pattern is how to integrate ideal industry which is supervision in balance based on each portion.

In general, the media coverage of sports news is wellknown with its pattern of pre-match report, during the match and post-match report. From those three aspects media constantly inserts colorful elements. The first element is how to report news full of conflictainment, a conflict that can trigger people to follow it as an entertainment. How media presents profiles, conflicts prior to a match are reviewed in order to direct the readers or audiences to observe a match from a number of aspects that even sometimes do not surprisingly relate to the sports. Political, sociological, psychological aspects are presented in such a way. Then the second is a report during the match in which atmosphere built by the reviewers are packaged attractively because after a match, there must be interesting topics being discussed.

The meaningful report is related to the process of coaching. Media coverage always gives a side effect especially psychological aspect that media unavoidably has robust influence. The influence on the one hand can trigger intern factor or a factor motivating an athlete, on the other it can discourage the athlete's spirit.

Perceptions must be constructed on how to take advantage of the blank space on the media by willingness though there is sometimes hidden agenda behind its coverage. For example, in broadcasting news journalists usually have significant role in determining the output of the news on whether athletes will be terrorized to influence their performance or instead they will be appraised for the encouragement during a competition. Because it becomes the choice of journalists, they will have particular strategy to report news. Media usually encourages athletes before a competition in order to be superior than the rivals. Chris john, for example, was reported negatively because of the influence of his psychological condition that relates to the market and industry of media. The key is on how media has the willingness to report news, negatively or positively.

According to a communication expert Turnomo Raharja, there is always an inextricable relation between media and sport. Sport becomes one of the commodities of media as it can become commodity of the marketable issue. Athlete with all of their fame, achievement and personal life can become the commodity by the media. Related to the media coverage, the conceptual frameworks media shall have three parameters. First, what has been reported by media must be based on facts. Further, the facts should be able to be verified, tested and should avoid criticism without any evidence. The estuary of all coverage is truthful that any news covered by the media should be based on facts. Actually the media coverage is a result of construction as the media has its own interest. When reporting an athlete with high achievement, there must be an interest behind it whether related to political, economical interest or others. That means the media cannot be value-free, cannot be in a blank space, independent, objective, without any prejudice, and having hidden interest. Many examples show the alignments of media towards particular group. The 
next question that shall be addressed is whether or not media coverage especially media criticism can influence the achievement of athletes. As a matter of fact, causalistic thinking should not be used; if athletes are criticized, their achievement will be declined; on the other hand there is a possibility that media criticism can encourage athletes to achieve more. Media only becomes a small part of athletes' achievement and the improvement or decline of an achievement is not merely due to media coverage. We cannot use positivistic thinking or causalistic thinking anymore. Essentially it depends on how the athlete processes information. The critics in media can be a tool for encouraging achievement or instead discouraging the spirit of the athlete.

Further, Ade Usman a journalist of Wawasan newspaper explains that media cannot be value-free. In other words, there is always an agenda and impossible to not favor on one interest. Basically that interest is caused by the effect of situation and condition that later on determine the percentage of influence; whether minority or minority depends on its own situation. A journalist must be in favor of one interest, what makes the difference is the degree.

From a psychological aspect, according the expert Ferdinat Hindarto the Vice Rector III of Unika Soegiyapranata Semarang explains, emphasizing what has been stated by Turnomo Raharjo, that the relation between media coverage and psychological aspect is not a causalistic relation, there is an intervening variable. Take for example boxing, during the preparation of PraPON Mataram when media reported the same pictures for two days consecutively in which coincidentally the athlete in that picture was less likeable by his friends. Consequently, the other athletes are angry and dislike the journalist who covered the picture. Another example is from football when a player is harshly criticized on the media due to his unwanted manner. Because the athlete is a foreign player who cannot speak Indonesian fluently, he proudly shows the news whereas in fact he was being criticized. It indicates that the influence of media coverage gives diverse and complex effects.

According to Yudo coach, Amin Pambudi states that mass media is immensely contributive in the development of sport since positive coverage from the various media in the form of reinforcement will give positive impact for the athletes; on the other hand criticism will offend the athletes. On that condition, athletes tend to be nervous during the practice. The role of mass media in sports development is very essential particularly during a competition. When athletes are exposed, their spirit will be higher afterwards the positive feeling will encourage them to achieve the expected goal. It happens because the exposure from media is actually the will of the society thus the athletes shall perform the best.

Suhardjono, a coach of roller skate states that media can build the excitement of an athlete for achievement, critics on the media are reasonable. Therefore, athletes who excel shall be covered in a media for a promotion thus it will inflict their pride.

From the perspective of an athlete, Roller skates athletes expresses that very often mass media improvises by their own interpretation in making the news. Occasionally, mass media looks for information without asking the athletes but other people. The information is not accurate. Hence, it bothers the athletes because their privacy is opened to public.

A judo athlete expresses that journalists do not understand his choice. The media describes him as an arrogant and rude athlete but from that moment he has better self-control to minimize the critics in the future. Mass media has an important role for an athlete as a constructive criticism shall be accepted as reality. In fact, not all critics addressed by mass media discouraged athletes; instead they encouraged athletes to control themselves better.

Meanwhile Taekwondo athlete, also expresses that the media coverage will not disturb her because she just wants to show the best and makes people proud of her achievement. Therefore, in her opinion media coverage will not influence her performance during a competition.

A wushu athlete, does not have any problem with media coverage because their real intention is to compete and she fully directs her attention on what will happen on the game, not outside of it. Further, her focus is on her rival and herself because it can help bring the best of her on the game. Related to the response of an athlete when reporting on newspaper, wushu athlete further reveals the first feeling appeared after the media coverage is excitement because it shows the attention of media. According to her experience during a competition on Pra PON and won, if there were no critics from the mass media she would have the winning point. On the other hand, if the mass media criticized her decreased speed, she would remember that and put her best effort to improve her performance. In fact the critics on the media are helpful in improving her weakness.

In the current development of sport, the remarkable role of press or mass media has been brought even closer. Indeed, media seemingly becomes an inextricable part of the development which shall be managed well in order to positively impact on the sport achievement. Whenever athletes are exposed on a media, their spirit will be higher as their happiness is linked to the level of expectation on personal achievement. It is just as likely to happen because athletes perceive that the media coverage is a part of society interest which shoul be fulfilled. It is immensely important, therefore, to cover high achiever athletes for the sake of public promotion and the increase of their pride simultaneously.

In responding the negative coverage, athletes' interpretation genuinely depends on themselves. The truth is that not all media criticisms are demotivating them but critics sometimes encourage the athletes to have better self-control thus positive influence will come along. Accordingly, criticism on media perhaps becomes a motivation for athletes to improve their performances.

Athletes who have robust goal setting during certain competition will not be hampered by media as they focus on showing the best and make others or the nation become proud of their impressive achievement. Here, their interest is only on the game not on the matter beyond the competition. 
Correspondingly, they are focusing on their rivals and themselves expecting to finish the game as well as possible.

From the perspective of psychology, it should be closely examined that the interconnected relation between media coverage with psychological aspect is not causalistic relation because there exist intervening variables. The first influencing psychological aspect is personal goal setting when athletes totally dedicate themselves on sports. In this case, if the determination is strong, other variables will follow and not easily influence by the inevitable external tensions.

The next aspect related to the media coverage is self confidence. Somehow athletes need to build their confidence by not only internal but also external factors. Motivation becomes the third aspect in which not only positive but also positive news perhaps become the source of motivation. When the critic influences atheltes' performance, it is the responsibility of a coach to respond towards it. Here, the critical media is permissible as long as it is proportional in the appropriate area.

The fourth aspect is intelligence in which the athletes' ability to manage information will be, of course, determined by their intelligence. When reading a media coverage, athelets can be excessively flattered because they cannot appropriately manage the information due to misperception.

Further, personality influences the psychology of athletes. In addition, its dimensions are numerous including on how an athlete should be trained to have attribution. Attribution is interpreted as a mindset to examine the cause of a failure or success.

The sixth aspect is focus and flow on how athletes can turn away anything which is unlikely related to the competition. Therefore, they can truly focus on the competition and put their best effort on the game including ignorance in responding both positive and positive media coverage.

Lastly, stress management and burn out become the seventh influencing psychological aspect of athletes. Attending regional or national training programmes in a few days, weeks or a month maybe can still make atheletes delightfully enjoy the activity. However, after months of doing the repeated activity over and over again will eventually make them feel bored. In this case, media can take on the role of this aspect which sometimes unthinkable. Media is like a knife which can be utilized as a useful cooking utensil or a harmful weapon for killing. The most crucial thing is on how athletes use or manage the information from the media.

Amidst the influence of media, there is an intervening variable which is personality variable. It relates to the theory that every individual naturally possess the need for exhibition to show up and perform. The excessive urge will negatively impact the athletes thus the news should be proportionally managed.

Indeed, media does not constantly become the single variable in influencing atheletes through negative coverage since their ability to manage the information will likewise affect them. The referred levels can be classified into three: intelligence, achievement and types of personality.

\section{CONCLUSIONS}

Athletes actually feel delighted when media covers them. The news in media can boost their motivation and popularity. At this level, positive news covered in mass media makes them feel proud. In contrast, news covering the weaknesses of athletes can bring about self-reflection and self-improvement. It is clear that the negative news sometimes possibly become motivation for athletes compared to the impact of positive news.

The interpretation of negative news on the mass media depends on the athletes. In particular, the level of athletes really determines the management of incoming information. The referred level can be divided into three: intelligence, achievement and types of personality. From the perspective of athletes' achievement, elite athletes certainly have robust, independent and solid personality as well as above average intelligence.

\section{ACKNOWLEDGMENT}

This study was granted from DIKTI. At last, authors would like to say thank you very much to participants who gave their contribution in this study.

\section{REFERENCES}

[1] Bompa. Tudor. O, Haff. G. Gregory, "Periodization, Theory and Methodology of Training", Human Kinetics, 2009.

[2] Karlene, Sugarman, MA. Winning the Mental Way. Burlingane CA: STep Up Pub. 2007

[3] Buttler. Richard, "Sports Psychology in Action”, CRS Press, 2015

[4] Jarvis. Matt, "Sport Psychology, A Student's Handbook", Routledge, 2006

[5] Pawluch. Dorothy, Shaffir. Willam, Miall Charlene, "Doing E18thnography”, Canadian Scholars' Press Inc., 2005

[6] Milles, Mattew B, Huberman. A. Michael, "Qualitative Data Analisis, A Methods Sourcebook”, SAGE Publication. Inc., 2013

[7] Elijah G. Rintaugu, Peter, W. Mwangi dan Mwisukha Andanje. 2011. The influence of mass media in socialization into sport of Kenya secondary school athletes. International Journal of Current Research, Vol 3 issue 11, pp 471-475. ISSN: 0975-833X.

[8] J. Eduardo Aguilar, Soledad Jorge, Ana Rubio dan G. Samuel Siris. 2011. Effect of mass media on suicidal behavior in patients with psychotic disorders. Mass media ISBN: 978-1-61728-863-0. Nova Science Publishers, inc.

[9] Jan Boehmer, Stephen Lacy. 2014. Sport News on Facebook: The Relationship Between Interactivity and Reader's Browsing Behavior. International Journal of Sport Communication, Volume 7, issue 1, March. 2014, 7, 1-15

[10] John W. Mahoney, Daniel F. Gucciardi, Nikos Ntoumanis, Cliff J. Mallett. 2014. Mental Toughness in Sport: Motivational Antecedents and Association with Performance and Psychological Health. JSEP, Volume 36 Issue 3, June. 2014, 26, 281-292, corrected July 7, 2014.

[11] Jong Wu Jun., Hyung Min Lee. 2012. The Globalization of Sport and The Mass-Mediated Idendity of Hines Ward in South Korea. Journal Of Sport Management. Volume. 26. 103-112.

[12] Jonathan Lewis, Jennifer M Proffit. 2012. Bong Hits and Water Bottles: An Analysis of News Coverage of Athletes and Marijuana Use. JSEP. Volume 7, Number 1, spring 2012 pp. 1-12|10.1353/jsm.2012.0009,

[13] Journal of Sport Media, Volume 3, Number 1, Sping 2008, pp 1-25. Published by University of Nebraska Press. DOI 10.1353/jsm.2008.0003

[14] Mehdi Moradi. 2012. Investigating the Role of Sport Media in developing Educational Sport. International Journal of Academic Research in Bussines and Sosial Sciences. Volume 2, No. 6 ISSN: 226990 
[15] Mohammadbagher Forghini Ozrudi, Mojtaba Bararzadeh, Mina Khanjani, Hamireza Fatahi. 2013. The role of mass media in studen's sport development at mazandaran province. International Journal of Sport Studies, Vol 3(1), 20-23. ISSN 2251-7502, Victor Quest Publications

[16] Salman Farzalipour, Cengiz Akalan, Semiyha Tuncel, Behrouz Ghprbanzadeh, Mir Majid Kashef, Mehrdad Moharram Zadeh, Nayyer Hajizadeh. 2012. The role of mass media in women's sport. Scholars Research Library, European Journal of Sport and Exercize Science. Volume 1(1): 6-13. ISSN: 2278-005X,
[17] Dustin A. Hahn, R. Glenn Cummins. 2014. Effects of Attractiveness, Gender, and Athlete-Reporter Congruence on Perceived Credibility of Sport Reporters. International Journal of Sport Communication, Volume 7, Issue 1, March. 2014, 7, 34-47

[18] Sherlley Wigley, Patrick C. Meirick. 2008. Interactive Media and Sport Journalist: The Impact of Interactive Media on Sports Journalist diterbitkan dalam Journal of Sport Media. Volume 3, Number . pp 1-25. Published by University of Nebraska Press. DOI 10.1353/jsm.2008.0003. 